\title{
Ortak Bilgi Yapılandırma Modeline Dayalı Fen Öğretiminin Sekizinci Sınıf Öğrencilerinin Bilimsel Bilginin Doğası Hakkındaki Görüşlerine Olan Etkisinin İncelenmesi
}

\section{Ilke Yıldırım ${ }^{1}$}

\author{
Hasan Bakırci ${ }^{2}$
}

Type/Tür:

Research/Araştırma

Received/Geliş Tarihi: June 1/ 1

Haziran 2020

Accepted/Kabul Tarihi:

December 11/ 11 Aralık 2020

Page numbers/Sayfa No: $627-648$

Corresponding

Author/Illetişimden Sorumlu

Yazar:

hasanbakirci09@gmail.com

\section{$\checkmark$ iThenticate}

This paper was checked for plagiarism using iThenticate during the preview process and before publication. / Bu çalışma ön inceleme sürecinde ve yayımlanmadan önce iThenticate yazılımı ile taranmıştır.

Copyright $(2017$ by

Cumhuriyet University, Faculty of Education. All rights reserved.

\begin{abstract}
Öz
Son yıllarda fen öğretiminde kullanılan öğretim modellerinden birisinin de Ortak Bilgi Yapılandırma Modeli (OBYM) olduğu söylenebilir. Bu modeli diğer öğretim modellerinden ayıran temel özelliklerinden birisi, bilimin ve bilimsel bilginin doğası üzerine odaklanmış olmasıdır. Bu çalışmanın amacı, OBYM'ye dayalı fen öğretiminin sekizinci sınıf öğrencilerinin bilimsel bilginin doğası görüşlerine olan etkisini araştırmaktır. Çalışmada deneysel araştırma desenlerinden, ön-son test kontrol gruplu yarı deneysel desen kullanılmıştır. Çalışma grubunu, 2017-2018 eğitim-öğretim yılında Van ilinin Tuşba ilçesinde bir ortaokulda 25'i deney ve 25 'i kontrol grubundan olmak üzere toplam 50 öğrenci oluşturmaktadır. Çalışmada veriler, Bilimsel Bilginin Doğası Ölçeği (BİBDÖ) aracılığıyla toplanmıştır. Çalışmada elde edilen veriler; bağıml ve bağımsız t-testi kullanılarak analiz edilmiştir. BİBDÖ'nün tüm alt boyutları açısından, deney ve kontrol grubu öğrencilerinin ön ve son test puanları arasında anlamlı bir farklılık bulunmuştur. Deney ve kontrol grubu öğrencilerinin BİBDÖ son test puanları kıyaslandığında, deney grubu lehine anlamlı bir farklılık olduğu görülmüştür. Sonuç olarak, deney grubunda uygulanan OBYM'ye ve kontrol grubunda uygulanan 5E öğrenme modeline dayalı fen öğretiminin sekizinci sınıf öğrencilerinin bilimsel bilginin doğası üzerinde etkili olduğu tespit edilmiştir. Deney ve kontrol grubu öğrencilerinin bilimsel bilginin doğası hakkındaki görüşleri karşılaştırıldığında, deney grubundaki öğrencilerin görüşlerindeki değişimin daha fazla olduğu belirlenmiştir. OBYM'ye dayalı fen öğretiminin bilimsel bilginin doğası üzerinde etkisinin daha net olarak görülebilmesi için farklı öğretim kademelerinde öğrenim gören öğrenciler ile benzer çalışmaların yürütülmesi önerilmektedir.
\end{abstract}

Anahtar Kelimeler: Fen eğitimi, ortak bilgi yapılandırma modeli, bilimsel bilginin doğası, bilimin doğası, sekizinci sınıf öğrencileri

\section{Suggested APA Citation/Önerilen APA Atıf Biçimi:}

Yıldırım, İ., \& Bakırcı, H. (2021). Ortak bilgi yapılandırma modeline dayalı fen öğretiminin sekizinci sınıf öğrencilerinin bilimsel bilginin doğası hakkındaki görüşlerine olan etkisinin incelenmesi. Cumhuriyet International Journal of Education, 10(2), 627-648. http://dx.doi.org/10.30703/cije.746710

\footnotetext{
1Uzman Fen Bilimleri Öğretmeni, Milli Eğitim Bakanlığı, Bursa/Türkiye

Expert Science Teacher, The Ministry of Education, Bursa/Turkey

e-mail: ilkeyildirim91@hotmail.com ORCID ID: orcid.org/0000-0003-0131-491X

2 Doçent Dr., Van Yüzüncü Yıl Üniversitesi, Van/Turkiye

Associate Professor, Van Yüzüncü Yil University, Van/Turkey

e-mail: hasanbakirci09@gmail.com ORCID ID: orcid.org/0000-0002-7142-5271
}

${ }^{3}$ Bu çalışma, birinci yazarın yüksek lisans tezinin bir bölümünden oluşmaktadır. 


\title{
The Effect of Science Teaching Based on the Common Knowledge Construction Model: Investigation of Eighth Grade Students' Opinions on the Nature of Scientific Knowledge
}

\begin{abstract}
One of the teaching models used in science teaching in recent years is the Common Knowledge Construction Model (CKCM). An important aspect of this model is that unlike other teaching models, it focuses on the nature of science and scientific knowledge. The purpose of this study is to investigate the effect of science teaching based on the Common Knowledge Construction Model drawing on eighth grade students' views on the nature of scientific knowledge. This research employed quasi-experimental design with pre-post test control group. The participants are 50 students, 25 of whom are in the experimental group and 25 of them make up the control group, in a secondary school in the town of Tusba, Van, in the 2017-2018 academic year. The data in the study were collected through the Nature of Scientific Knowledge Scale (NSKS) and were analyzed using the dependent and independent t-test. A significant difference was found between the pre-test and post-test scores of the students in the experimental and control groups in terms of all sub-scales of the NSKS. When the posttest scores of the students in the experimental and control groups were compared, it was seen that there was a significant difference in favor of the experimental group. As a result, it was determined that science teaching based on 5E learning model applied to NSKS in the experimental group and to the control group was effective on the nature of scientific knowledge of eighth grade students. When the opinions of the experimental and control group students about the nature of scientific knowledge were compared, it was noted that the change in the opinions of the students in the experimental group was greater. In order to see the effect of science teaching based on NSKS on the nature of scientific knowledge more clearly, it is recommended to conduct similar studies with students studying at different education levels.
\end{abstract}

Keywords: Science education, common knowledge construction model, nature of scientific knowledge, nature of science, eighth grade students.

\section{Giriş}

Fen eğitiminin temel amaçlarından biri de öğrencilerin fen okuryazarı bireyler olarak yetişmesini sağlamaktır (American Association for the Advancement of Science [AAAS], 1990). Öğrencilerin fen okuryazarı bireyler olarak yetişmelerinde bilimin doğası büyük önem taşımaktadır. Bilimin doğası; bilim insanlarının ve bilimsel bilginin özelliklerini içermesinin yanı sıra bilimsel tartışmalara katılmayı, bilimsel yayınları okumayı ve bilimin toplumu nasıl etkilediğini kapsamaktadır (Driver, Leach, Millar ve Scott, 1996). Fen eğitiminde bilimin doğası, fen okuryazarlı̆̆ının anahtar bileşeni olarak kabul edilmektedir (National Research Council [NRC], 1996). Öğrencilerin fen okuryazarı olmaları, günümüzde birçok çevresel, sosyal ve ekonomik problemlere çözüm oluşturmaktadır (Moss, 2001). Günlük hayatta öğrencilerin karşılaştı̆̆ bu sorunları çözmeleri için bilimin doğasının öğretilmesi gerekmektedir (Hand, Prain, Lawrence ve Yore, 1999). Bu açıdan öğrencilerin bilimin ve bilimsel bilginin doğasını öğrenmeleri önemli bir ihtiyaç haline gelmiştir (Küçük, 2006). Dolayısıyla öğrencilere, fen öğretim programı çerçevesinde bilimin doğasının öğretilmesinin daha faydalı olacağı vurgulanmaktadır (NRC, 1996). Bilimin doğası kavramı, 2005 Fen ve Teknoloji Dersi Öğretim Programı' nda dolaylı olarak yer alırken, 2013 Fen Bilimleri Dersi Öğretim Programı'nda ise doğrudan yer almıştır (Milli Eğitim Bakanlı̆̆1 [MEB], 2013). 
Millî Eğitim Bakanlığı tarafından 2005 Fen ve Teknoloji Dersi Öğretim Programı'nda (FETDÖP) ilk defa önemli değişiklikler yapılmıştır. İlkokul ve ortaokul öğretim kademelerinde çağın gereklerine uygun olarak FETDÖP, 2013 yılında güncellenmiş ve vizyonu fen okuryazarı bireyler yetiştirmek olarak belirlenmiştir (MEB, 2013). Programda bireyin fen okuryazarlığ1; bilimsel teorilere, ilkelere, becerilere, tutum ve değerlere sahip olması ile ilişkilendirilmiştir. Bunun yanında bireyin, teknoloji-bilim-çevre ve toplum gibi kavramlar arasındaki ilişkinin farkında olması da önem arz etmektedir (Abd-El Khalick, Bell ve Lederman, 1998). Diğer taraftan 2018 yılında tekrar güncellenen FETDÖP'te, fen okuryazarlığına katkı sağlamak için Fen-Teknoloji-Mühendislik ve Matematik (FeTeMM) disiplinlerini esas alan öğretim anlayışı benimsenmiştir (MEB, 2018). Bu bilgiler 1şı̆̆ından fen okuryazarlık kavramına bakıldığında, bireylerin fen okuryazarı olmalarında onlara bilimin doğası ve içeriğinin kazandırılması önemli rol oynamaktadır. Çünkü bireylerin fen okuryazarı olmalarında, bilimin doğası temel aşama olarak görülmektedir. Böylece bireylerde bilimin doğası anlayışını geliştirerek çağdaş fen eğitiminin temel amacına katkı sağlanmaktadır (Lederman, 1992).

21. yüzyılın başlarından itibaren üzerinde araştırmaların yapıldığı bir konu alanı olan bilimin doğası, modern eğitim felsefelerinin içerisinde kendine her zaman bir yer bulmuştur ve bireylerin fen okuryazarı olmalarını amaçlamıştır. Bu amaç doğrultusunda bireylerin bilimin doğası hakkında yeterli anlayışa sahip olabilmeleri bir gereklilik haline gelmiştir (Khishfe, 2013; Lederman, 2007). Literatürde bilimin doğasıyla ilgili teori ve yasa unsurunun öğrenciler tarafından zor anlaşıldığına ve bu engelin aşılması için etkili materyaller tasarlanmasının gerekliliğine vurgu yapılmaktadır. Aynı zamanda bilimsel teori ve yasalar açılanırken örneklendirme yapılmalı ve bu örneklerde teori ve yasa arasındaki farklara dikkat çekilmelidir (Ayvacı ve Özbek, 2015). Ayrıca bilimin doğası unsurlarından biri olan bilim tarihinin öğretiminde kullanılan Fen Bilimleri ders kitaplarında yer alan tartışma metinlerinin yeterli ve dikkat çekici olmadığ1 tespit edilmiştir (Koçyiğit ve Pektaş, 2017; Takaoğlu, 2018). Literatürde vurgulanan bir diğer problem ise eğitim fakültesi öğrencilerinin bilimsel bilginin özellikleri ve bilimin doğası konusunda alternatif kavramlara sahip olmalarıdır (Bora, 2005; Kartal ve Ada, 2018). Bilimin doğası ile ilgili alanyazın incelendiğinde; öğrencilerin modern bilim insanını zihinlerinde canlandıramadıkları ve bilim insanlarının bilimsel bilgiye ulaşmasına dair işleyişleri yeterli düzeyde bilmedikleri tespit edilmiştir (Eyceyurt-Türk ve Tüzün, 2017). Başka bir çalışmada sınıf düzeyi arttıkça, öğrencilerin bilimin doğasını anlamaya yönelik inançları ve araştırma sorgulama becerilerinin geliştiği saptanmıştır. Bilimin doğasını anlama ve fen dersindeki akademik başarı arasında olumlu ilişki olduğu belirlenmiştir (Öztürk ve Kaplan, 2014). Öğretmen adaylarının bilimin doğası ve bilimsel bilginin özellikleriyle ilgili sahip oldukları alternatif kavramların giderilmesi gerektiği vurgulanmıştır (Kartal ve Ada, 2018; Yenice ve Ceren-Atmaca, 2017).

Son yıllarda fen öğretiminde bilimin ve bilimsel bilginin doğasına önemli ölçüde yer verilmektedir. Çünkü bilimin doğasının öğrenciler tarafından anlaşılmasının, onların fen okuryazar olmalarına büyük katkı sağladı̆̆ı tespit edilmiştir (Bakırcı, Çalık ve Çepni, 2017). Bu nedenle öğrenciler için fen okuryazarlık konusunda etkili olan öğretim yaklaşım ve modellerinin fen öğretiminde kullanılmasına dikkat çekilmektedir. Bu öğretim modellerinden birisinin de son 
yıllarda fen ve kimya öğretiminde kullanılan Ortak Bilgi Yapılandırma Modeli (OBYM) olduğu söylenebilir. Bu modeli diğer öğretim modellerinden ayıran temel özelliklerinden birisi de modelin bilimin ve bilimsel bilginin doğası üzerine odaklanmış olmasıdır (Bakırc1, 2014; Ebenezer ve Connor, 1998). OBYM'nin bilimin doğası konusunda, 5, 6 ve 7. sinıfta öğrenim gören öğrenci görüşleri üzerinde olumlu etki oluşturduğu birçok çalışmada ortaya konulmuştur (Bakırcı, Çalık ve Çepni, 2017; Bakırcı ve Çiçek, 2017). OBYM'ye dayalı fen öğretiminin 8. sınıf öğrencilerinin bilimsel bilginin doğası üzerinde etkisinin olup olmadığına dair herhangi bir çalışmaya rastlanmamıştır. Bundan dolayı OBYM'nin sekizinci sınıf öğrencilerinin bilimsel bilginin doğası üzerinde etkisinin araştırılması önem arz etmektedir.

Yapılandırmacı ve araştırma sorgulamaya dayalı öğrenme yaklaşımlarının özelliklerini barındıran OBYM Ebenezer ve Connor tarafından ilk olarak 1998 yılında oluşturulmuş bir öğretim ve öğrenim modelidir. Bu model, Bruner'in dili kültürün sembolik sisteminin bir üyesi olarak algılamasından, Vygotsky'nin yakınsal gelişim alanından ve Doll'un bilimsel söylem ve post modern düşüncelerinden esinlenilerek geliştirilmiştir (Biernacka, 2006). Marton'un “Öğrenme Varyasyonu Teorisi'ne ve Piaget'in kavramsal değişim çalışmalarını da yapıtaşı olarak dikkate almıştır (Ebenezer, Chacko, Kaya, Koya ve Ebenezer, 2010). Bu öğrenme modeli, fen öğrenme ortamında dört aşamalı olarak kullanılmaktadır (Bakırcı vd., 2017). Bu aşamalar; Keşfetme ve Sinıflandırma, Yapılandırma ve Müzakere Etme, Transfer Etme ve Genişletme, Yansıtma ve Değerlendirme şeklinde sıralanmıştır.

Keşfetme ve Sınıflandırma, öğrencilerin hazır bulunuşluklarının tespit edildiği, dikkat çekme ve güdülenmeyi de içerisinde barındıran derse giriş aşamasıdır. Öğrencileri bilimin doğasından haberdar etme ve konuyla ilgili fenomenografik kategorilerin oluşturulması bu aşamada yer almaktadır. Konuyla ilgili öğrencilerin sahip oldukları alternatif kavramların farkına varmaları sağlanmaktadır (Biernacka, 2006). Yapılandırma ve Müzakere Etme aşamasında; öğrenciler kendilerinde var olan alternatif kavramları değiştirmenin; eleştirel düşünme, araştırma ve akran paylaşımı gibi süreçlerin sonunda zihinde oluşan dengesizlikler sayesinde olabileceğinin farkına varırlar (Ebenezer ve Connor, 1998). Öğretmenler, öğrencilerin konu ile ilgili deney ve uygulama etkinlikleri yapmaları için ortam hazırlar ve iş birliğine dayalı etkinlikler yaparak, bilimsel araştırma hakkında bilgi sahibi olmalarını sağlar (Wood, 2012). Bilginin zihinde yapılandırılması öğretmen-öğrenci ve öğrenci-öğrenci etkileşimi sürecinde yapılan eylemler sayesinde gerçekleşir. Bu aşamada öğrenciler yeni edindikleri bilgileri kendilerinde var olan bilgilerle birleştirerek yapılandırmaya çalışırlar (Brown ve Ryoo, 2008).

Transfer Etme ve Genişletme aşamasında; öğrenciler yapılandırma ve görüşme aşamasında öğrendikleri bilgileri günlük hayatta farklı durumlara transfer ederek bilginin kullanılmasını sağlar. Öğrenciler sosyobilimsel konulardaki problemler için ulusal ya da uluslararası seviyede çözüm bulmaya çalışırlar (Biernacka, 2006; Ebenezer vd., 2010). Fen, teknoloji, toplum ve çevre (FTTÇ) bağlamını fen bilgisi eğitiminde kullanmanın amacı; öğrencilere konular hakkında ortak bir şekilde karar alırken sosyal sorumluluğu öğretmek ve öğrencilere bilimin sosyal ve kültürel olarak yaşamla iç içe bulunduğunu göstermektir (Biernacka, 2006; Ebenezer vd., 2010). Bu aşamada öğretmen, öğrencilerin üst düzey düşünme becerilerini geliştirmek ve diğer alanlara transfer etmek için planlar yapmalıdır. Ayrıca öğrencilerin görüşlerini 
derinleştirmesine yardımcı olmalı ve disiplinler arası bağlantıları kurmalarını sağlamalıdır. Yansıtma ve Değerlendirme aşamasında; öğrencilerin alternatif ölçme değerlendirme tekniklerinin kullanarak konuyu öğrenip öğrenmediklerinin araştırıldığı aşamadır. Burada öğrenciler yaptıkları çalışmaları sunarlar. Öğretmenler de bu süreçte değişik tekniklerle öğrencilerin neler öğrendiklerini, hangi düzeyde öğrendiklerini ve nasıl öğrendiklerini ölçmektedir. Bu değerlendirme aynı zamanda öğrencilerin kavramsal değişim sürecin de bilgiyi nasıl öğrendiği, nasıl keşfettiği, zihninde nasıl yapılandırdığı üzerinde de durur (Biernacka, 2006).

Bilimsel bilginin doğası ile ilgili çalışmalar daha çok öğretmen adayları ile yürütülmüştür (Gül ve Erkol, 2016). Bu çalışmalarda, öğretmen adaylarının bilimsel bilginin doğasına yönelik görüşlerinin genel anlamda orta düzeyde olduğu saptanmıştır (Yenice ve Ceren-Atmaca, 2017). Bugünün ortaokul öğrencileri, yarının öğretmen adayları ve öğretmenleri olacağı için, erken yaşlarda bilimin doğası ve bilimsel bilginin doğası anlayışı üzerine odaklanan öğrenme ortamları oluşturmanın literatürdeki bu eksikliğin giderilmesine katkı sağlayacağı düşünülmektedir. Bunun yanı sıra OBYM'ye dayalı fen öğretiminin esas alındığı çalışmalarda, çalışma grubu olarak sekizinci sınıf öğrencilerine yönelik yapılan çalışmaların yetersiz olduğu söylenebilir (Yıldırım ve Bakırcı, 2020). Alanyazındaki bu bilgiler 1şı̆̆ında bilimin doğasının öğretim üzerine odaklanan OBYM'nin, sekizinci sınıf öğrencilerinin bilimsel bilginin doğası üzerindeki etkisinin belirlenmesi önem arz etmektedir.

OBYM ile gerçekleştirilecek öğrenme sürecinin, öğrencilerin bilimin doğasına yönelik görüşlerinde değişiklik yaratabileceği düşünülmektedir. OBYM'nin odaklandığı sosyobilimsel konular, bilimin doğası ve girişimcilik gibi konular Fen Bilimleri Dersi Öğretim Programı́nda önemli yer tutmaktadır (MEB, 2018). Bu açıdan bakıldığında OBYM'nin Fen Bilimleri dersinde kullanılmasının, programın amacına yönelik katkı sağlayacağına inanılmaktadır (Bakırcı vd., 2017). OBYM'nin ikinci aşamasında; öğrencilerin bilimsel bilginin sadece bilimsel metotlardan olan deney, gözlem, ispatlama ile elde edilmediğini; görüşme, paylaşma, müzakere etme gibi sosyal boyutlarla da ortaya çıkarılabileceğinin belirlenmesi bilimin doğası öğretiminde OBYM'nin kullanılmasının etkili olacağını desteklemektedir (Biernacka, 2006; Ebenezer ve Connor, 1998). Ayrıca, OBYM'de öğretmenlerin kılavuzluğunda bilginin sosyal anlamda da yapılandırılması için bilimsel söylem yapılmaktadır (Duschl ve Osborne, 2002). Bu da bilimin doğasının içeriklerinden birini destekler niteliktedir. Genel olarak bakıldığında OBYM'nin, Fen Bilimleri dersinde kullanılması literatüre katkı sağlayacağı düşünülmektedir. Bu çalışmanın temel problemi; “OBYM' ye dayalı fen öğretiminin sekizinci sınıf öğrencilerinin bilimsel bilginin doğası hakkındaki görüşleri üzerinde etkisi var mıdır?" şeklinde tanımlanmıştır. Bu temel araştırma soru kapsamında aşağıdaki sorulara cevap aranmıştır:

Deney ve kontrol grubu öğrencilerinin Bilimsel Bilginin Doğası Ölçeği (BİBDÖ) ön test puanları arasında istatistiksel olarak anlamlı bir fark var midır?

Deney ve kontrol grubu öğrencilerinin BİBDÖ ön ve son test puanları arasında istatistiksel olarak anlamlı bir fark var midır?

Deney ve kontrol grubu öğrencilerinin BİBDÖ son test puanları arasında istatistiksel olarak anlamlı bir fark var mıdır? 


\section{Araştırmanın Deseni}

\section{Yöntem}

OBYM'ye dayalı fen öğretiminin sekizinci sınıf öğrencilerinin bilimsel bilginin doğası üzerinde etkisinin araştırıldığı bu çalışmada deneysel yöntemlerden yarı deneysel yöntem kullanılmıştır. Bu desende, daha önce okul idaresi tarafından belirlenmiş olan gruplar içinde rastgele atama yoluyla kontrol ve deney grubu belirlenmektedir. Deney ve kontrol grubunun olabildiğince benzer özellikte olmasına özen gösterilmektedir (Çepni, 2018). Bu araştırmada deney ve kontrol grubunun benzer özellikte olabilmesi için öğrencilerin çalışmadan önceki dönemdeki yıl içi genel başarı ortalamaları dikkate alınarak çalışma grupları oluşturulmuştur. OBYM'ye dayalı fen öğretiminin etkisini araştırmak için önceden okul idaresi tarafından rastgele dağılım dışında oluşturulmuş sınıflardan biri deney ve diğeri ise kontrol grubu olarak belirlenmiştir.

\section{Çalışma Grubu}

Bu araştırma, 2017-2018 eğitim-öğretim yılında Van ilinin Tuşba ilçesine bağlı bir köy ortaokulunda 25 'i deney (10 k1z, 15 erkek) ve 25'i kontrol grubundan (9 k1z, 16 erkek) olmak üzere toplam 50 öğrencinin katılımı ile gerçekleştirilmiştir. Çalışma grubu, kolay ulaşılabilir örneklem tekniği ile belirlenmiştir. Bu tekniğin kullanılmasında, araştırmacının çalışmanın yapıldığı okulda çalışıyor olması, tekniğin ekonomik olması, araştırmacılara hız ve pratiklik kazandırma gibi özellikler etkili olmuştur (Yıldırım ve Şimşek, 2013). Deney ve kontrol grupları kendi aralarında kura ile belirlenmiştir. Araştırmanın yapıldığı okulda 8/A, 8/B ve 8/C olmak üzere üç şube bulunmaktadır. Bu üç şubenin geçen dönemdeki yıl içi genel başarısı dikkate alınarak çalışma grubu belirlenmiştir. Geçen dönem yıl içi genel başarı sonucuna göre 8/A ve 8/B şubelerinin bu konuda başarı düzeyleri birbirine yakın olduğu tespit edilirken, 8/C şubesinin başarı düzeyinin diğer iki şubeden farklı olduğu belirlenmiştir. Bu sonuçlar doğrultusunda 8/C şubesi çalışma grubuna dâhil edilmemiştir. Bu iki şubenin kontrol ve deney grubu olmasında kura ile seçim yapılarak 8/ A'nın deney grubu, 8/B şubesinin ise kontrol grubu olmasına karar verilmiştir.

\section{Uygulama}

Deney ve kontrol grubunda, uygulama altı hafta (24 ders saati) sürmüştür. Bu uygulama, Maddenin Yapısı ve Özellikleri ünitesi ile sınırlıdır. Deney ve kontrol grubunda uygulama, 2018 Fen Bilimleri Dersi Öğretim Programı temelinde yürütülmüştür. Kontrol grubunda dersler, araştırma-sorgulamaya dayalı öğrenme yaklaşımı temelinde 5E öğrenme modeli ile yürütülmüştür. Deney grubunda dersler OBYM'ye göre işlenmiştir. Deney ve kontrol grubundaki dersler aynı öğretmen ile yürütülmüştür. Öğretmen, OBYM ile ilgili iki haftalık hizmet içi kurs programına katılmıştır. Kontrol grubunda dersler Milli Eğitim Bakanlığı'nın önerdiği Fen Bilimleri ders kitabı doğrultusunda yürütülmüştür. Deney grubundaki dersler ise, Fen Bilimleri ders kitabına ek olarak araştırmacılar tarafından geliştirilen öğretim materyalleri kullanılarak gerçekleştirilmiştir. Bu çalışmada bilimin doğasının; bilimsel bilginin kesin olmayışı, deneysel, sosyal, hayal gücü ve yaratıcılık boyutu ele alınmıştır. Aşağıda deney grubuna uygulanan OBYM temelli fen öğretiminin bir haftalık ders planı ayrıntılı olarak açıklanmıştır.

Keşfetme ve sınıflandırma aşaması. Öğretmen, öğrencilere periyodik tabloyla ilgili bir dersin işleneceğini söyleyerek, bu dersin kazanımları hakkında kısaca bilgi 
verdi. Daha sonra, bilim insanı ve bilimsel bilginin doğası kavramlarının ne olduğunu sınıfa sordu. Öğrencilerin bu konudaki görüşlerini ortaya çıkarmak için beyin fırtınası tekniği kullanıldı. Öğretmen tarafından tüm öğrencilerin görebileceği bir yere periyodik tablo asıldı. Ardından her öğrenciye boş bir periyodik tablo fotokopisi dağıtıldı. Öğrencilerin tahtadaki periyodik tabloya bakarak kendilerine dağıtılan periyodik tabloyu doldurmaları beklendi. Bu doldurma esnasında öğrencilerin bu periyodik tabloda nelerin olduğunu ve nasıl oluşturulduğunu düşünmeleri istendi. Öğrenciler tabloları doldurup renklendirdikten sonra düşüncelerini sözel olarak ifade ettiler. Periyodik tablonun oluşturulmasında yer alan bilim insanlarının katkılarının neler olduğunu kısaca belirten "Periyodik Tablonun Tarihçesi" adlı etkinlik öğrencilere uygulandı ve öğrencilerden etkinlik içerisindeki soruların cevaplarını yazmaları istendi. Bu etkinliğin amacı, bilimin doğasının unsurlarından birisi olan "bilimsel bilginin değişebilir doğası" ile ilgili öğrencilerin görüş açısı kazanmalarını sağlamaktır.

Yapılandırma ve müzakere etme aşaması. Periyodik tablonun tarihçesi etkinliğinden gelen yanıtlar doğrultusunda sınıfta tartışma düzenlenerek öğrencilerin bu konudaki görüşleri ortaya çıkarıldı. Bu etkinlikle hem periyodik tablonun tarihsel gelişimine bilim insanlarının yaptığı katkılar hem de "Bilimsel bilgi değişebilir", "Bilimsel bilgi özneldir", "Bilimsel bilgi birikimlidir" vb. gibi bilimin doğası boyutları öğrencilere kazandırıldı. Daha sonra öğrencilere "Periyodik tablodaki elementlerin yerleşim düzeninin belirli bir kuralı var midır?" sorusu yöneltildi. Sınıfa diğer bilim insanlarının tasarladıkları periyodik tablolar da asıldı ve öğrencilerden karşılaştırma yaparak ne tarz kuralların olabildiğini, farklılık ve benzerliklerinin neler olduğunu bulmaları istendi. $\mathrm{Bu}$ aşamada öğrencilere periyodik tabloya yeni bir element ekleyecek olsalar nasıl bir element keşfedip ismini ne koyacakları da sorulup öğrencilerin hayal gücü ve yaratıcılıklarını kullanmaları sağland1.

Genişletme ve transfer etme aşaması. Öğrencilere periyodik tablonun tarihçesi ve elementlerin periyodik tabloya nasıl yerleştirildiği önceki etkinliklerden çıkarımlar yardımıyla öğretildi. Bu öğrenmeden sonra öğrencilere elementlerin katmanlara dağılımını göstermek için analoji tekniğini temel alan çalışma kâğıdı dağıtıldı. Çalışma kâğıtları yönergelere uygun olarak yapıldı. Öğrencilerden de elektron katman ilişkisini gösterecek modelleme yapmaları istendi. Yeni olarak bulunan ve periyodik tabloya eklenilen elementle ilgili örnek olay metni öğrencilere sunuldu ve öğrencilerden ilgili soruları cevaplandırmaları istendi. Öğrencilerden gelen cevaplar sinıf ortamında tartışıldı.

Yansıtma ve değerlendirme aşaması. Öğrencilerin konuyu ne kadar öğrendiklerini ortaya çıkarmak amacıyla Tanılayıcı Dallanmış Ağaç, Kavram Haritası ve Yapılandırılmış Grid kullanıldı. Öğretmen gelen yanıtlara göre dönütler verdi ve değerlendirme işlemi sonlandırıldı.

Aşağ1da kontrol grubuna uygulanan 5E öğrenme modeline dayalı fen öğretiminin bir haftalık ders planı ayrıntılı olarak açıklanmıştır.

Girme. Öğretmen öğrencilerine "Maddenin Yapısı ve Özellikleri” ünitesinin işleneceğini söylerken bu derste işlenecek kazanımlara kısaca değindi. Böylece dersin içeriği hakkında öğrenciler haberdar edildi. Ders kitabında bulunan "Periyodik Sistem" konusunun anlatıldığı sayfalardaki resim ve fotoğrafları öğrencilerin 
incelenmesi istendi. Resim ve fotoğraflarla anlatılmak istenen bilginin ne olduğu hakkında öğrencilerin tahminleri alındı. Kitaptaki resim ve fotoğrafları inceleyen öğrencilere 7. sınıf bilgilerinden elementler ve sembolleri konusu ile Periyodik Sistem konusu arasında bir bağlantı olup olmadığı soruldu.

Keşfetme. Öğretmen, sınıf duvarına Periyodik Tablo'nun posterini astı ve bu poster hakkında görüş bildirmek isteyen öğrencilere söz hakkı verdi. Öğrencilere "Sizce Periyodik Tablo nasıl oluşturulmuştur ve bu tablonun oluşturulması sırasında ne gibi adımlar izlenmiştir?" sorusu yöneltti. Ardından Periyodik Tablo'nun oluşmasında katkı sağlayan bilim insanlarının isimleri ve periyodik tablonun oluşum sürecine katkıları tahta üzerinde farklı yerlere yazıldı. Öğrencilerden tahtadaki bilim insanlarının isimleri ve Periyodik Tablo'ya katkılarının eşleştirilmesi istendi. Öğrenciler periyodik tablo oluşturulurken birden fazla bilim insanının katkı sağladığını ve bilim insanlarının sunduğu bilgilerin yeni araştırmalarla çürütülebileceğini gördüğü için öğrencilerin bu aşamada ünite kazanımlarının yanı sıra bilimin doğası unsurlarından "Bilimsel bilgi değişebilir ve Bilimsel bilgi birikimlidir" kazanımlarının da farkına varmaları amaçlandı.

Açıklama. Bu aşamada öğrenciler Periyodik Sistem'in nasıl oluştuğunu kendi cümleleriyle açıklamaları istendi. Buna ek olarak periyot ve grup kavramlarını da eşleştirme sırasında keşfeden öğrencinin bu kavramları periyodik tablo üzerinde göstermeleri sağlandı. Ayrıca öğretmen, öğrencilerine elementlerin tablodaki yerleşimlerinde bir kural olup olmadığını sordu. Böylece Periyodik Tablo' da bulunan periyot ve gruplardaki düzenin nasıl olduğu öğrenciye sezdirildi.

Derinleştirme. Bu aşamada öğrencilere, keşfetme basamağında bahsedilmiş olan bilim insanları ve bu bilim insanlarının periyodik tabloya yaptıkları katkılar hatırlatıldı. Ayrıca bu bilim insanlarının tasarladıkları Periyodik Tablo çizimleri de öğrencilere sunuldu. Öğrencilere bu aşamada, bilim insanlarının farklı düşünce yapılarına sahip olmasından kaynaklı periyodik tabloya yaptıkları katkıların farklı olması ve bilimin doğası konusunda "Bilimsel bilginin öznel olduğunu” çıkarımı vurguland1. Periyodik tabloda yer alan elementlerin elektron-katman ilişkilerini daha kolay anlayabilmeleri için soğanın katmanlı yapıda olması benzetmesi yapıldı. Soğanın merkezinde bulunan yumrusu ve elementlerin merkezleri eşleştirilirken soğanın katmanlarıyla da elementlerin yörüngeleri bağdaştırıldı. Elementlerin periyodik tabloda bulundukları yerleri tespit edebilmek amaçlı elektron-katman ilişkisi için öğrencilere örnek çizimler verildi ve Periyodik Tablo'da bulunan ilk 18 elementin elektron-katman ilişkisini defterlerine çizmeleri istendi.

Değerlendirme. Öğrencilerin Maddenin Yapısı ve Özellikleri ünitesindeki Periyodik Sistem konusuyla ilgili ders kitabında yer alan etkinlikleri ve alıştırmaları yapma durumları kontrol edildi. Bunlara ek olarak öğrencilere konu sonunda mini bir sınav yapıldı ve kavram haritasıyla öğrencilerin hedeflenen kazanımlara ulaşılıp ulaşılmadı̆̆ belirlendi.

\section{Veri Toplama Araçları}

Bu çalışmada, Rubba ve Anderson (1978) tarafından geliştirilen, Türkçe'ye çevirisi ve uyarlanması Taşar (2006) tarafından yapılan Bilimsel Bilginin Doğası Ölçeği (BİBDÖ) kullanılmıştır. 
Bilimsel bilginin doğası ölçeği (BİBDÖ). BİBDO, bilimin doğasının temel boyutlarını içermektedir. Bahsedilen boyutlar ve boyutlarda yer alan ifadelerin olumlu ya da olumsuz yargı bildirme durumları Tablo 1'de gösterilmiştir.

Tablo 1

BİBDÖ'de Yer Alan Olumlu ve Olumsuz Madde Numaralarn

\begin{tabular}{lcc}
\hline \multicolumn{1}{c}{ Bilimsel Bilginin Doğasının Alt } & Olumlu Maddeler & Olumsuz Maddeler \\
Boyutları & & $7,18,21,36$ \\
\hline Ahlaki & $4,5,8,48$ & $1,23,34,41$ \\
Yaratıcılik & $17,20,28,32$ & $25,27,31,43$ \\
Gelissimsel & $16,26,37,42$ & $14,15,39,40$ \\
Sadelik & $2,6,29,46$ & $9,11,13,33$ \\
Test edilebilirlik & $12,22,38,45$ & $10,19,24,44$ \\
Birleştirme & $3,30,35,47$ & \\
\hline
\end{tabular}

Beşli Likert tipi ölçme tarzında olan BİBDÖ toplamda 48 maddeden oluşmaktadır. Ölçekte yer alan maddelerin 24 tanesi olumlu özellik gösterirken, diğer 24 madde ise olumsuz özellik göstermektedir. Öğrencilerden ölçekte verilen maddeler için "Tamamen Katıllyorum", "Katılıyorum", "Kararsızım”, “Katılmıyorum” ve "Hiç Katılmıorum" ifadelerinden kendine uygun olan bir ifadeyi seçmesi istenmektedir. Olumlu ifadeler sirasıyla 5, 4, 3, 2, 1 olacak şekilde, olumsuz ifadeler ise sırasıyla 1, 2, $3,4,5$ olacak şekilde puanlandırılmaktadır. Buna göre ölçekten alınabilecek en fazla puan 240, en az puan ise 48 olarak hesaplanmaktadır.

Ölçek; ahlaki, yaratıcılık, gelişimsel, sadelik, test edilebilme ve birleştirme başlıklı altı alt boyuttan oluşmaktadır. Alt boyutların Cronbach's Alpha güvenirlik katsayıları ahlak alt boyutu için 0.87, yaratıcılık alt boyutu için 0.87 , gelişimsel alt boyutu için 0.86 , sadelik alt boyu için 0.86 , test edilebilme alt boyutu için 0.86 ve birleştirme alt boyutu için 0.86 olarak bulunmuştur. Ölçeğin tamamına ilişkin Cronbach's Alpha güvenirlik katsayısı 0.84 olarak hesaplanmıştır. Bu değerler, bilimsel bir çalışma için uygun olarak kabul edilmektedir (Büyüköztürk, 2017).

BİBDÖ'nün güvenirliği araştırmacılar tarafından tekrar hesaplanmıştır. BİBDÖ, araştırmacılar tarafından Van il merkezinde altı farklı ortaokulda öğrenim gören toplam 421 sekizinci sını öğrencisine uygulanmıştır. Veriler, SPSS 22.0TM programına girilerek BİBDÖ'nün güvenirlik katsayısı (a) hesaplanmıştır. BİBDÖ' de yer alan alt boyutların güvenirlik katsayıları sırasıyla; ahlaki $(\alpha=0.85)$, yaratıclık $(\alpha=0.84)$, gelişimsel $(\alpha=0.81)$ ve sadelik ( $\alpha=0.82)$, test edilebilme $(\alpha=0.83)$ ve birleştirme $(\alpha=0.86)$ şeklinde bulunmuştur. BİBDÖ'nün toplam güvenirlik katsayısı, 0.83 olduğu tespit edilmiştir. BİBDÖ'nün alt boyutları ve ölçeğinin tamamının Cronbach Alpha katsayılarının 0.80 'in üzerinde olduğu için ölçeğin güvenilir olduğu söylenebilir (Büyüköztürk, 2017).

\section{Verilerin Analizi}

BİBDÖ'den elde edilen veriler, SPSS 22.0 $0^{\mathrm{TM}}$ paket programına girilmiştir. SPSS paket programına girilen veriler, analiz edilmeden önce bazı istatistiksel teknikler kullanılarak verilerin dağ 11 mı incelenmiştir. Bu işlem sonucunda verilerin normal dağılım gösterdiği görülmüştür ( $\mathrm{p}>0.05)$. Bu yüzden verilerin analizinde parametrik testler kullanılmıştır (Büyüköztürk, 2017). Deney ve kontrol gruplarının 
karşılaştırılmasında parametrik testlerden bağımsız t-testi kullanılırken, grupların kendi içinde karşılaştırmalarında ise bağımlı t-testi tercih edilmiştir.

\section{Bulgular}

Deney ve kontrol grubu öğrencilerinin Bilimsel Bilginin Doğası Ölçeği (BİBDÖ) ön test puanlarının bağımsız t-testine göre kıyaslanması Tablo 2' de sunulmuştur.

Tablo 2

Deney ve Kontrol Grubu Öğrencilerinin BİBDÖ Ön Test Puanlarmın Boyutlara Göre Karşılaştırılmasına İlişkin Bağımsız T-testi Sonuçları

\begin{tabular}{cccccccc}
\hline Boyutlar & Gruplar & $\mathbf{N}$ & $\bar{X}$ & $\mathbf{S}$ & $\mathbf{s d}$ & $\mathbf{t}$ & $\mathbf{p}$ \\
\hline \multirow{2}{*}{ Ahlaki } & Deney & 25 & 23.92 & 2.85 & 45 & -.541 & .592 \\
\cline { 2 - 8 } & Kontrol & 22 & 24.40 & 3.34 & & & \\
\hline \multirow{2}{*}{ Yaratıcıllk } & Deney & 25 & 26.68 & 3.69 & 45 & .306 & .761 \\
\cline { 2 - 8 } & Kontrol & 22 & 26.31 & 4.40 & & & \\
\hline \multirow{2}{*}{ Gelişimsel } & Deney & 25 & 23.36 & 4.51 & 45 & .686 & .496 \\
& Kontrol & 22 & 22.54 & 3.47 & & & \\
\cline { 2 - 8 } & Deney & 25 & 23.36 & 3.42 & 45 & -.821 & .416 \\
\cline { 2 - 8 } Sadelik & Kontrol & 22 & 24.13 & 2.99 & & & \\
\hline \multirow{2}{*}{ Test } & Deney & 25 & 24.68 & 3.53 & 45 & -1.423 & .162 \\
\cline { 2 - 7 } Edilebilirlik & Kontrol & 22 & 26.18 & 3.69 & & & \\
\hline \multirow{2}{*}{ Birleştirme } & Deney & 25 & 26.68 & 3.42 & 45 & \multirow{2}{*}{1.599} & .117 \\
\cline { 2 - 7 } & Kontrol & 22 & 25.00 & 3.77 & & & \\
\hline
\end{tabular}

Deney grubu öğrencilerinin BİBDÖ’nün ahlaki boyut ön test puanlarının aritmetik ortalaması 23.92 iken, kontrol grubu öğrencilerinin aritmetik ortalamasının ise 24.40 olduğu tespit edilmiştir. Bu ortalamalar bağlamında deney ve kontrol grubu öğrencilerinin BİBDÖ'nün ahlaki boyutunun ön test puanları arasında anlamlı bir farkın olmadığ1 görülmektedir $\left[\mathrm{t}_{(45)}=-.541, \mathrm{p}>\right.$.05]. BİBDÖ'nün yaratıcılık boyutuna bakıldığında deney grubu öğrencilerinin ön test puanlarının aritmetik ortalaması 26.68 iken, kontrol grubu öğrencilerinin aritmetik ortalaması ise 26.31 olduğu tespit edilmiştir. Ortalamalar kıyaslandığında deney ve kontrol grubu öğrencilerinin BİBDÖ'nün yaratıcılık boyutunun ön test puanları arasında anlamlı bir farkın olmadı ğı görülmektedir $\left[\mathrm{t}_{(45)}=.306, \mathrm{p}>.05\right]$. Tablodan deney grubu öğrencilerinin BİBDÖ'nün gelişimsel boyut ön test puanları incelendiğinde aritmetik ortalama 23.36 olarak bulunmuş, kontrol grubu öğrencilerinin aritmetik ortalaması ise 22.54 olduğu gözlenmiştir. Bu ortalamalar kapsamında deney ve kontrol grubu öğrencilerinin BİBDÖ'nün gelişimsel boyutunun ön test puanları arasında anlamlı bir farkın olmadığ1 görülmektedir $\left[\mathrm{t}_{(45)}=.686, \mathrm{p}>.05\right]$. BİBDÖ'nün sadelik boyutu incelendiğinde deney grubu öğrencilerinin ön test puanlarının aritmetik ortalaması 23.36 iken, kontrol grubu öğrencilerinin aritmetik ortalaması ise 24.13 olduğu gözlenmiştir. Ortalamalar doğrultusunda deney ve kontrol grubu öğrencilerinin BİBDÖ'nün sadelik boyutunun ön test puanları arasında anlamlı bir farkın olmadığ1 tespit edilmiştir $\left[\mathrm{t}_{(45)}=-.821\right.$, 
p>.05]. BİBDÖ'nün test edilebilirlik boyutun da ise deney grubu öğrencilerinin ön test puanlarının aritmetik ortalaması 24.68 iken, kontrol grubu öğrencilerinin aritmetik ortalaması ise 26.18 olduğu görülmektedir. Ortalamalar bağlamında deney ve kontrol grubu öğrencilerinin BİBDÖ'́nün test edilebilirlik boyutunun ön test puanları arasında anlamlı bir farkın olmadığı görülmektedir $\left[\mathrm{t}_{(45)}=-1.423, \mathrm{p}>\right.$.05]. BİBDÖ'n nün birleştirme boyutu araştırıldığında deney grubu öğrencilerinin ön test puanlarının aritmetik ortalaması 26.68 iken, kontrol grubu ögrencilerinin aritmetik ortalaması ise 25.00 olduğu anlaşılmıştır. Ortalamalar dikkate alındığında deney ve kontrol grubu öğrencilerinin BİBDÖ'nün birleştirme boyutunun ön test puanları arasında anlamlı bir farkın olmadığı görülmektedir [ $\mathrm{t}_{(45)}=1.599, \mathrm{p}>$.05].

Deney grubu öğrencilerinin BİBDÖ ön ve son test arasındaki anlamlılı̆̆ın bağımlı t-testine göre kıyaslanması Tablo 3'te sunulmuştur.

Tablo 3

Deney Grubu Öğrencilerinin BİBDÖ Ön ve Son Test Arasındaki Anlamlılı̆̆a İlişkin Bă̆ımlı T-Testi Sonuçları

\begin{tabular}{cccccccc}
\hline Boyutlar & Test & $\mathbf{N}$ & $\bar{X}$ & $\mathbf{S}$ & $\mathbf{s d}$ & $\mathbf{t}$ & $\mathbf{p}$ \\
\hline \multirow{2}{*}{ Ahlaki } & Ön test & 25 & 23.92 & 2.85 & 24 & -10.66 & .000 \\
\cline { 2 - 8 } & Son test & 25 & 33.28 & 2.30 & & & \\
\hline \multirow{2}{*}{ Yaratıcıl1k } & Ön test & 25 & 26.68 & 3.69 & 24 & -8.38 & .000 \\
\cline { 2 - 8 } & Son test & 25 & 32.20 & 2.56 & & & \\
\hline \multirow{2}{*}{ Gelişimsel } & Ön test & 25 & 23.36 & 4.51 & 24 & -10.11 & .000 \\
\cline { 2 - 8 } & Son test & 25 & 33.48 & 1.75 & & & \\
\hline \multirow{2}{*}{ Sadelik } & Ön test & 25 & 23.36 & 3.42 & 24 & -8.60 & .000 \\
\cline { 2 - 8 } & Son test & 25 & 30.96 & 2.26 & & & \\
\hline \multirow{2}{*}{ Test } & Ön test & 25 & 24.68 & 3.53 & 24 & -7.71 & .000 \\
\cline { 2 - 8 } & Son test & 25 & 32.52 & 2.69 & & & \\
\hline \multirow{2}{*}{ Birleştirme } & Ön test & 25 & 26.68 & 3.42 & 24 & -9.53 & .000 \\
\cline { 2 - 7 } & Son test & 25 & 33.72 & 2.35 & & & \\
\hline
\end{tabular}

Deney grubu öğrencilerinin BİBDÖ'nün ahlaki boyutu ön ve son test puanları arasında anlamlı bir farklilık bulunmuştur $\left[\mathrm{t}_{(24)}=-10.66, \mathrm{p}<.001\right]$. Deney grubu öğrencilerinin uygulama öncesinde ahlaki boyut puanlarının aritmetik ortalaması 23.92 iken, uygulama sonrası 33.28'e yükseldiği görülmektedir. Deney grubu öğrencilerinin BİBDÖ'nün yaratıcılık boyutunun ön ve son test puanları karşılaştırıldığında anlamlı bir fark olduğ tespit edilmiştir $\left[\mathrm{t}_{(24)}=-8.38, \mathrm{p}<.001\right]$. Deney grubu öğrencilerinin uygulama öncesinde yaratıcılık boyut puanlarının aritmetik ortalaması 26.68 iken, uygulama sonrası 32.20'ye yükseldiği görülmektedir. Deney grubu öğrencilerinin BİBDÖ'nün gelişimsel boyutunun ön ve son test puanları arasında anlamlı bir farklilık bulunmuştur $\left[\mathrm{t}_{(24)}=-10.11, \mathrm{p}<.001\right]$. Deney grubu öğrencilerinin uygulama öncesinde gelişimsel boyut puanlarının aritmetik ortalaması 23.36 iken, uygulama sonrası $33.48^{\prime}$ e yükseldiği görülmektedir. Deney grubu 
öğrencilerinin BİBDÖ'nün sadelik boyutunun ön ve son test puanları arasında anlamlı bir farklılık bulunmuştur $\left[\mathrm{t}_{(24)}=-8.60, \mathrm{p}<.001\right]$. Deney grubu öğrencilerinin uygulama öncesinde sadelik boyut puanlarının aritmetik ortalaması 23.36 iken, uygulama sonrası 30.96'ya yükseldiği görülmektedir. Deney grubu öğrencilerinin BİBDÖ’́nün test edilebilirlik boyutunun ön ve son test puanları arasında anlamlı bir farklılık tespit edilmiştir $\left[\mathrm{t}_{(24)}=-7.71, \mathrm{p}<.001\right]$. Deney grubu öğrencilerinin uygulama öncesinde test edilebilirlik boyut puanlarının aritmetik ortalaması 24.68 iken, uygulama sonrası 32.52'ye yükseldiği görülmektedir. Deney grubu öğrencilerinin BİBDÖ’nün birleştirme boyutunun ön ve son test puanları arasında anlamlı bir farklılık olduğu gözlenmiştir $\left[\mathrm{t}_{(24)}=-9,53, \mathrm{p}<.001\right]$. Deney grubu öğrencilerinin uygulama öncesinde birleştirme boyut puanlarının aritmetik ortalaması 26.68 iken, uygulama sonrası 33.72'ye yükseldiği görülmektedir.

Kontrol grubu öğrencilerinin BİBDÖ ön ve son test arasındaki anlamlılı̆̆ın bağımlı t-testine göre kıyaslanması Tablo 4 'te sunulmuştur.

Tablo 4

Kontrol Grubu Öğrencilerinin BİBDÖ Ön ve Son Test Arasındaki Anlamlılı̆̆a İlişkin Bă̆ımlı T-Testi Sonuçları

\begin{tabular}{cccccccc}
\hline Boyutlar & Test & $\mathbf{N}$ & $\bar{X}$ & $\mathbf{S}$ & $\mathbf{s d}$ & $\mathbf{t}$ & $\mathbf{p}$ \\
\hline \multirow{2}{*}{ Ahlaki } & Ön test & 22 & 24.40 & 3.34 & 21 & -7.52 & .000 \\
\cline { 2 - 8 } & Son test & 22 & 30.95 & 1.83 & & & \\
\hline \multirow{2}{*}{ Yaratıcıl1k } & Ön test & 22 & 26.31 & 4.40 & 21 & -4.82 & .000 \\
\cline { 2 - 8 } & Son test & 22 & 31,50 & 2.65 & & & \\
\hline \multirow{2}{*}{ Gelişimsel } & Ön test & 22 & 22.54 & 3.47 & 21 & -13.37 & .000 \\
\cline { 2 - 8 } & Son test & 22 & 30.86 & 1.64 & & & \\
\hline \multirow{2}{*}{ Sadelik } & Ön test & 22 & 24.13 & 2.99 & 21 & -6.47 & .000 \\
\cline { 2 - 8 } & Son test & 22 & 29.40 & 2.46 & & & \\
\hline \multirow{2}{*}{ Test } & Ön test & 22 & 26.18 & 3.69 & 21 & -4.47 & .000 \\
\cline { 2 - 5 } & Son test & 22 & 30.13 & 3.05 & & & \\
\hline \multirow{2}{*}{ Birleştirme } & Ön test & 22 & 25.00 & 3.77 & 21 & -6.13 & .000 \\
\cline { 2 - 7 } & Son test & 22 & 31.09 & 2.09 & & & \\
\hline
\end{tabular}

Kontrol grubu öğrencilerinin BİBDÖ'nün ahlaki boyutunun ön ve son test puanları arasında anlamlı bir farklılık bulunmuştur [ $\left.\mathrm{t}_{(21)}=-7.52, \mathrm{p}<.001\right]$. Kontrol grubu ögrrencilerinin uygulama öncesinde ahlaki boyut puanlarının aritmetik ortalaması 24.40 iken, uygulama sonrası 30.95'e yükseldiği görülmektedir. BİBDÖ'n nün yaratıcılık boyutunun ön ve son test puanları kıyaslandığında anlamlı bir farklılık olduğunu tespit edilmektedir $\left[\mathrm{t}_{(21)}=-4.82, \mathrm{p}<.001\right]$. Kontrol grubu öğrencilerinin uygulama öncesinde yaratıcılık boyut puanlarının aritmetik ortalaması 26.31 iken, uygulama sonrası 31.50'ye yükseldiği görülmektedir. BİBDÖ'nün gelişimsel boyutunun ön ve son test puanları arasında anlamlı bir farklılık olduğu görülmektedir $\left[t_{(21)}=-13.37, p<.001\right]$. Kontrol grubu öğrencilerinin uygulama öncesinde gelişimsel boyut puanlarının aritmetik ortalaması 22.54 iken, uygulama sonrası 30.86'ya 
yükseldiği görülmektedir. BİBDÖ'nün sadelik boyutunun ön ve son test puanları arasında anlamlı bir farklılık olduğu dikkat çekmektedir $\left[\mathrm{t}_{(21)}=-6.47, \mathrm{p}<.001\right]$. Kontrol grubu öğrencilerinin uygulama öncesinde sadelik boyut puanlarının aritmetik ortalaması 24.13 iken, uygulama sonrası 29.40'a yükseldiği görülmektedir. BİBDÖ’n nün test edilebilirlik boyutunun ön ve son test puanları arasında anlamlı bir farklılık bulunmuştur $\left[\mathrm{t}_{(21)}=-4.47, \mathrm{p}<.001\right]$. Kontrol grubu öğrencilerinin uygulama öncesinde yaratıcılık boyut puanlarının aritmetik ortalaması $26.18 \mathrm{iken}$, uygulama sonrası 30.13 'e yükseldiği görülmektedir. BİBDÖ'nün birleştirme boyutunun ön ve son test puanları incelendiğinde puanlar arsında anlamlı bir farklılık tespit edilmiştir $\left[\mathrm{t}_{(21)}=-6.13\right.$, $\mathrm{p}$ <.001]. Kontrol grubu öğrencilerinin uygulama öncesinde birleştirme boyut puanlarının aritmetik ortalaması 25.00 iken, uygulama sonrası 31.09'a yükseldiği görülmektedir.

Deney ve kontrol grubu öğrencilerinin BİBDÖ son test puanlarının bağımsı ttestine göre kıyaslanması Tablo 5'te sunulmuştur.

Tablo 5

Deney ve Kontrol Grubu Öğrencilerinin BİBDÖ Son Test Puanlarının Boyutlara Göre Karşılaştırılmasına İlişkin Bă̆ımsız T-testi Sonuçları

\begin{tabular}{cccccccc}
\hline \multirow{2}{*}{ Boyutlar } & Gruplar & $\mathbf{N}$ & $\bar{X}$ & $\mathbf{S}$ & $\mathbf{s d}$ & $\mathbf{t}$ & $\mathbf{p}$ \\
\hline \multirow{2}{*}{ Ahlaki } & Deney & 25 & 33.28 & 2.30 & 45 & 3.79 & .000 \\
\cline { 2 - 8 } & Kontrol & 22 & 30.95 & 1.83 & & & \\
\hline \multirow{2}{*}{ Yaratıc1lık } & Deney & 25 & 32.20 & 2.56 & 45 & .919 & .363 \\
\cline { 2 - 8 } & Kontrol & 22 & 31.50 & 2.65 & & & \\
\hline \multirow{2}{*}{ Gelişimsel } & Deney & 25 & 33.48 & 1.75 & 45 & 5.24 & .000 \\
\cline { 2 - 8 } & Kontrol & 22 & 30.86 & 1.64 & & & \\
\hline \multirow{2}{*}{ Sadelik } & Deney & 25 & 30.96 & 2.26 & 45 & 2.25 & .029 \\
\cline { 2 - 8 } & Kontrol & 22 & 29.40 & 2.46 & & & \\
\hline \multirow{2}{*}{ Test Edilebilirlik } & Deney & 25 & 32.52 & 2.69 & 45 & 2.84 & .007 \\
\cline { 2 - 8 } & Kontrol & 22 & 30.13 & 3.05 & & & \\
\hline \multirow{2}{*}{ Birleştirme } & Deney & 25 & 33.72 & 2.35 & 45 & 4.02 & .000 \\
\cline { 2 - 7 } & Kontrol & 22 & 31.09 & 2.09 & & & \\
\hline
\end{tabular}

Deney grubu öğrencilerinin BİBDÖ'nün ahlaki boyut son test puanlarının aritmetik ortalaması 33.28 iken, kontrol grubu öğrencilerinin aritmetik ortalamasının ise 30.95 olarak bulunmuştur. Deney ve kontrol gruplarının son test puanlarına göre anlamlı bir fark olup, bu farkın deney grubu lehine olduğu görülmektedir $\left[\mathrm{t}_{(45)}=3.79\right.$, $\mathrm{p}<.001]$. Deney grubu öğrencilerinin BİBDÖ'nün yaratıcllı boyutunun son test puanlarının aritmetik ortalaması 32.20, kontrol grubu öğrencilerinin aritmetik ortalaması ise 31.50 olarak tespit edilmiştir. Deney ve kontrol gruplarının son test puanlarına göre anlamlı bir farka rastlanmamıştır [ $\left.\mathrm{t}_{(45)}=.919, \mathrm{p}>.05\right]$. Deney grubu öğrencilerinin BİBDÖ'nün gelişimsel boyutuna bakıldığında son test puanlarının aritmetik ortalaması 33.48, kontrol grubu öğrencilerinin aritmetik ortalaması 30.86 olarak bulunmuştur. Deney ve kontrol gruplarının son test puanlarına göre anlamlı 
bir fark olduğu gözlenmiş, bu farkın deney grubu lehine olduğu tespit edilmiştir [t $=5.24, \mathrm{p}<.001]$. Deney grubundaki öğrencilerinin BİBDÖ'nün sadelik boyutu son test puanlarının aritmetik ortalaması 30.96 iken, kontrol grubu öğrencilerinin aritmetik ortalamasının ise 29.40 olduğu gözlenmiştir. Deney ve kontrol gruplarının son test puanlarına göre anlamlı bir fark olduğu bu farkın deney grubu lehine olduğu görülmektedir $\left[\mathrm{t}_{(45)}=2.25, \mathrm{p}<.05\right]$. Deney grubundaki öğrencilerinin BİBDÖ'nün test edilebilirlik boyutu son test puanlarının aritmetik ortalamas1 32.52, kontrol grubu öğrencilerinin aritmetik ortalamasının ise 30.13 olarak bulunmuştur. Deney ve kontrol gruplarının son test puanlarına göre anlamlı bir fark olduğu bu farkın deney grubu lehine olduğu görülmektedir [ $\left.\mathrm{t}_{(45)}=2.84, \mathrm{p}<.05\right]$. Deney grubundaki öğrencilerinin BİBDÖ'nün birleştirilme boyutu son test puanlarının aritmetik ortalaması $33.72 \mathrm{iken}$, kontrol grubu öğrencilerinin aritmetik ortalamasının ise 31.09 olduğu tespit edilmiştir. Deney ve kontrol gruplarının son test puanlarına göre anlamlı bir fark olduğu ve bu farkın deney grubu lehine olduğu görülmektedir $\left[\mathrm{t}_{(45)}=4.02, \mathrm{p}<.001\right]$.

\section{Tartışma, Sonuç ve Öneriler}

Bu çalışmada, Ortak Bilgi Yapılandırma Modeline (OBYM)'ne dayalı fen öğretiminin sekizinci sınıf öğrencilerinin bilimsel bilginin doğası hakkındaki görüşlerine olan etkisinin araştırılması amaçlanmıştır. Bu amaç doğrultusunda araştırmada elde edilen bulgular incelendiğinde; deney ve kontrol grubu öğrencilerinin Bilimsel Bilginin Doğası Ölçeği (BİBDÖ)'nin ahlak, yaratıcılık, gelişim, sadelik, test edilebilme ve birleştirme boyutlarının ön test puanları arasında anlamlı bir farkın olmadığı bulunmuştur. Bu bulgu, uygulama öncesinde deney ve kontrol grubu öğrencilerinin bilimsel bilginin doğası konusundaki bilgilerinin birbirine yakın veya benzer olmasına işaret etmektedir. Elde edilen bu sonucun; ailelerin sosyoekonomik düzeylerinin yakın ve öğrencilerin aynı öğretmenlerden ders almış olmalarından, anne ve baba eğitim düzeylerinin eşit ya da yakın ve benzer öğrenme yaşantılarına sahip olmasından kaynaklandığ1 düşünülmektedir. Ön-son test desenli birçok çalışmada, öğrencilerin araştırılan değişken bağlamında ön bilgilerinin birbirine yakın ve benzer olduğu saptanmıştır. Sekizinci sınıf öğrencilerinin bilimsel bilginin doğası konusundaki ön bilgilerinin uygulama öncesinde benzer çıkması literatür açısından beklenen bir durumdur (Bakırcı, 2014; Sağdıç, 2018).

Deney grubu öğrencilerinin BİBDÖ'nün ahlak, yaratıcılık, gelişim, sadelik, test edilebilme ve birleştirme boyutlarının ön-test ve son-test puanları arasında anlamlı bir farklılık bulunmuş ve bu farklılı̆̆ın son test lehine olduğu belirlenmiştir. Bu bulgu; deney grubunda uygulanan OBYM'ye dayalı fen öğretiminin, öğrencilerin bilimsel bilginin doğası hakkındaki görüşleri üzerinde etkili olduğunu göstermektedir. Bu durumun, OBYM'nin birinci ve üçüncü aşamasında bilimin doğası ile ilgili yapılan etkinliklerden kaynaklandığı düşünülmektedir. Bu aşamalarda yapılan etkinlikler; bilimsel bilginin kesin olmaması, bilimsel bilginin deneysel boyutu ve bilim insanlarının yaratıcılık ve hayal gücü gibi bilimin doğasına dair unsurlara odaklanmaktadır. Nitekim bu konuda Bakırcı, Çalık ve Çepni (2017) ortaokul altıncı sınıf öğrencileri ile yürütmüş oldukları çalışmada, OBYM'ye dayalı fen öğretiminin öğrencilerin bilimsel bilginin doğası konusundaki görüşlerini olumlu etkilediğini saptamışlardır. Benzer şekilde, Bakırcı ve Çiçek (2017) yapmış oldukları çalışmada, OBYM'ye dayalı fen öğretiminin beşinci sınıf öğrencilerinin bilim doğası görüşlerinde etkili olduğunu tespit etmişlerdir. Ozan, Uluçınar-Sağır (2020) tarafında yapılan başka 
bir çalışmada ise, FeTeMM etkinliklerine dayalı fen öğretiminin beşinci sınıf öğrencilerinin bilim doğası anlayışlarının gelişmesinde etkili olduğunu saptamışlardır. Kısacası OBYM ile ilgili alanyazında yapılan çalışmaların sonuçları, bu çalışmada elde edilen sonuçlar ile benzerlik göstermektedir.

Kontrol grubu öğrencilerinde BİBDÖ'nün ahlak, yaratıcılık, gelişim, sadelik, test edilebilme ve birleştirme boyutlarının ön-test ve son-test puanları arasında sontest lehine anlamlı bir farklılık bulunmuştur. Bu durum, kontrol grubunda uygulan 5E öğrenme modeline dayalı fen öğretiminin öğrencilerin bilimsel bilginin doğası hakkındaki görüşleri üzerinde etkili olduğunu ortaya koymaktadır. Bu sonucun, 5E öğrenme modelinin keşfetme basamağında gerçekleştirilen deneyler sonrası bilimin doğası konusunda yapılan tartışmalardan kaynaklandığına inanılmaktadır. Çünkü bu aşamada bilimin doğasının deneyselliği, öznelliği ve bilimsel bilginin ortaya çıkmasında bilim insanlarının yaratıcılığı gibi unsurlar ele alınmaktadır. Bunun yanı sıra Fen Bilimleri ders kitabında yer alan bilimin doğası etkinliklerinin öğrencilerin bilimsel bilginin doğasını kavramaları üzerinde etkili olduğu düşünülmektedir. Bu sonucun, alanyazında yapılan bazı çalışmaların sonuçları ile örtüşmediği görülmüştür (Koçyiğit ve Pektaş, 2017; Takoğlu, 2018). Bu durumun, çalışmada kullanılan Fen Bilimleri dersi kitabının basıldığı yayın evi ile daha önce incelenen Fen Bilimleri ders kitabının yayın evinin farklı olmasından kaynaklandığı düşünülmektedir. Çünkü aynı ders kitabı farklı yayın evi tarafından basılmaktadır. Bundan dolayı bu kitaplarda yer alan etkinlikler ve bu etkinliklerin sayısı farklılık gösterebilmektedir. Milli Eğitim Bakanlığı belirli bir eğitim-öğretim yılında okutulacak kitaplara karar verirken birden fazla yayın evi kitabının okutulmasına karar vermektedir (Url-1, 2020). Bakırcı (2014) altıncı sınıf öğrencileriyle yaptığı çalışmada, 5E öğrenme modelinin öğrencilerin bilimin doğası görüşleri üzerinde etkili olduğunu saptamıştır. Başka bir çalışmada da, sekizinci sınıf öğrencilerinin bilimsel bilginin oluşum sürecini gözlemledikleri öğrenme ortamını daha çok tercih ettikleri görülmüştür (Özkal, 2007). Bu durum, en iyi öğrenmenin yaparak yaşayarak gerçekleştiğini ortaya koymaktadır. Özellikle 5E öğrenme modelinin keşfetme basamağında, öğrencilerin aktif olarak deney ve etkinliklere katılmalarının onların yaparak yaşayarak öğrenmelerine önemli katkı sağladı̆̆ı söylenebilir.

Deney ve kontrol gruplarının BİBDÖ son test puanları incelendiğinde; deney grubu lehine anlamlı istatistiksel bir farklılığın olduğu tespit edilmiştir. Bu sonuç, deney grubunda uygulanan OBYM temelli fen öğretiminin, kontrol grubunda uygulanan 5E öğrenme modeline göre öğrencilerin bilimsel bilginin doğasını anlamaları üzerinde daha etkili olduğu şeklinde yorumlanabilir. Bu anlamlı farkın, OBYM'nin; bilimin doğası, sosyobilimsel konular ve kavramsal değişim gibi farklı öğrenme alanlarına odaklanmasından kaynaklandığı söylenebilir. Çünkü bilimin doğası unsurlarının öğrencilere kazandırılması bu öğrenme alanlarının amaçları arasında yer almaktadır (Ebenezer vd., 2010). OBYM'nin ilk aşamasında, öğrencilerin bilimin doğası ile ilgili ön bilgilerini ortaya çıkaran etkinlikler yapılmakta, modelin üçüncü aşamasında ise bu konular ilgili tartışmalar yapılmaktadır. Deney grubunda öğrencilerin bilimsel bilginin doğası bilgilerinin kontrol grubu öğrencilerine göre iyi düzeyde olması, deneysel işlem kapsamında yapılan etkinliklerle doğrudan ilişkilendirilebilir (Bakırcı ve Çiçek, 2017). Biernacka (2006), beşinci sınıf öğrencileri ile yapmış olduğu çalışmasında OBYM'ye dayalı geliştirilen etkinliklerin, öğrencilerin 
bilimin doğasının deneysel unsurunu kavramaları üzerinde etkili olduğu sonucuna ulaşmıştır. Bu sonuca paralel olarak Bakırcı ve Çiçek (2017)'te yaptıkları çalışmada, OBYM'nin öğrencilerde gözlem ve çıkarım, hayal gücü, yaratıcılık gibi bilim doğasına dair unsurlarının anlaşılmasına katkı sağladığını bulmuşlardır. Bilimin doğasına ilişkin unsurların öğrenciler tarafından anlaşılması, onların bilimsel bilginin doğasını anlamalarına katkı sağlamaktadır (Caymaz ve Aydın, 2019). Bu konuda yapılan başka bir çalışmada Kardaş ve Şahin (2020), bilimsel hikâyelerin altıncı sınıf öğrencilerinin bilimin doğasını anlamada yeterli olmadığını bulmuşlardır.

Araştırmada dikkat çeken bulgulardan birisi de deney grubu ile kontrol grubunun son test puanları karşılaştırılmasında, BİBDÖ'nün yaratıcılık alt boyut puanları arasında anlamlı bir ilişkinin olmamasıdır. Bu durum, deney ve kontrol grubunda yapılan uygulamaların yaratıcılık boyutu üzerinde aynı düzeyde etkili olması ile açılanabilir. Başka bir ifade ile deney ve kontrol grubu öğrencilerinin yaratıcılık boyutunun son test puanlarının ortalamasının birbirine yakın olmasından kaynaklandığı düşünülmektedir. Bu konuda Adıyaman (2019), ortaokul yedinci sınıf öğrencileri ile yaptığı çalışmada, drama etkinliklerinin bilimsel bilginin özelliklerinin öğrenilmesinde önemli katkılar sağladığını tespit etmiştir. Özellikle öğrencilerin bilimin doğasının yaratıcılık ve hayal gücü unsurlarında vermiş oldukları yanıtların oldukça bilimsel olduğu görülmüştür. Bu çalışmada ulaşılan sonucun, Adıyaman'ın (2019) çalışmasının sonucu ile örtüştüğü görülmüştür. Nacaroğlu ve Arslan (2020), özel yetenekli öğrenciler ile yürüttükleri çalışmada, bilim insanlarının imaj ve özelliklerini araştırmışlardır. Çalışmanın sonunda özel yetenekli öğrenciler, bilim insanlarının yaratıcı ve sabırlı olma özelliğini ön plana çıkarmışlardır.

Araştırma kapsamında ulaşılan sonuçlardan hareketle aşağıdaki öneriler geliştirilmiştir:

1-OBYM'ye dayalı fen öğretiminin bilimsel bilginin doğasını anlamaları üzerinde etkisinin daha net olarak görülebilmesi için, farklı öğretim kademelerinde öğrenim gören öğrencilerle 5E öğrenme modeli uygulamalarına dayalı çalışmalar gerçekleştirilebilir.

2-OBYM'ye dayalı fen öğretiminin öğrencilerin bilimin doğası hakkındaki görüşleri üzerinde etkili olması nedeniyle Fen Bilimleri dersinde bu modelin kullanılmasının öğrencilerin fen okuryazarı birey olmalarına katkı sağlayacağı düşünülmektedir.

3-OBYM'nin Fen Bilimleri dersinde kullanılması öğrencilerin bilimsel bilginin özelliklerini öğrenmelerine katkı sağlayabilir.

\section{Kaynakça}

Abd-El-Khalick, F., Bell, R. L., and Lederman, N. G. (1998). The nature of science and instructional practice: Making the unnatural natural. Science Education, 82(4), 417-436. https:/ / doi.org/10.1002/(SICI)1098-237X(199807)82:4<417::AIDSCE1>3.0.CO;2-E

Adıyaman, A. K. (2019). Bilim ve bilimsel bilginin doğasının ortaokul 7. sinıföğrencilerine drama yöntemiyle öğretilmesi. (Yayımlanmamış yüksek lisans tezi). Trakya Üniversitesi, Edirne. 
American Association for the Advancement of Science (AAAS). (1990). Science for all Americans. Bench marks for scientific literacy. New York: Oxford University Press.

Ayvacı, H. Ş. ve Özbek, D. (2015). Fen teknoloji toplum dersi kapsamında yapılan uygulamaların fen bilimleri öğretmen adaylarının bilimin doğası algılarına etkisi. Hasan Âli Yücel Ĕ̈itim Fakültesi Dergisi, 12(1), 93-108.

Bakırcı, H. (2014). Ortak bilgi yapılandırma modeline dayalı ögretim materyali tasarlama, uygulama ve modelin etkililiğini değerlendirme çalışması: Işık ve ses ünitesi örneği. (Yayımlanmamış doktora tezi). Karadeniz Teknik Üniversitesi, Trabzon.

Bakırcı, H. ve Çiçek, S. (2017). Ortak bilgi yapılandırma modeline göre tasarlanan öğrenme ortamının 5. sınıf öğrencilerinin bilimin doğası üzerine etkisi. Journal of Social and Humanities Sciences Research, 4(15), 1960-1974.

https://doi.org/10.26450/jshsr.289

Bakırcı, H., Çalık, M. ve Çepni, S. (2017). The effect of the common knowledge construction model oriented education on sixth grade students' views on the nature of science. Journal of Baltic Science Education, 16(1), 43-55.

Biernacka, B. (2006). Developing scientific literacy of grade five students: A teacher researcher collaborative effort. University of Manitoba: Doctoral dissertation.

Bora, N. D. (2005). Türkiye genelinde ortaöğretim fen branşı öğretmen ve öğrencilerinin bilimin doğası üzerine görüşlerinin araştırılması. (Yayımlanmamış doktora tezi). Gazi Üniversitesi, Ankara.

Brown, B. A., and Ryoo, K. (2008). Teaching science as a language: A “content-first" approach to science teaching. Journal of Research in Science Teaching, 45(5), 529553. https:/ / doi.org/10.1002/tea.20255

Büyüköztürk, Ş. (2017). Sosyal bilimler için veri analizi el kitabı. Ankara: Pegem

Akademi Yayınc1lik. https:/ / doi.org/10.14527/9789756802748

Caymaz, B. ve Aydın, A. (2019). Ortak bilgi yapılandırma modelinin yedinci sınıf öğrencilerinin elektrik enerjisi ünitesine ilişkin kavramsal anlamalarına etkisi. Kastamonu Ĕ̆itim Dergisi, 27(5), 1955-1975.

https://doi.org/10.24106/kefdergi.3196

Çepni, S. (2018). Araştırma ve proje çalışmalarına giriş. Trabzon: Celepler Yayıncılık.

Driver, R., Leach, J., Millar, R., and Scott, P. (1996). Young people's images of science. Buckingham, UK: Open University Press.

Duschl, R., and Osborne, J. (2002). Supporting and promoting argumentation discourse. Studies in Science Education, 38, 39-72. https://doi.org/10.1080/03057260208560187

Ebenezer, J. V., and Connor, S. (1998). Learning to teach science: A model for the 21 century. Upper Saddle River, NJ: Prentice-Hall, Simon and Schuster/A Viacom Company.

Ebenezer, J., Chacko, S., Kaya, O. N., Koya, S. K., and Ebenezer, D. L. (2010). The effects of common knowledge construction model sequence of lessons on science achievement and relational conceptual change. Journal of Research in Science Teaching, 47(1), 25-46. https:// doi.org/10.1002/tea.20295

Eyceyurt-Türk, G. ve Tüzün, Ü. N. (2017). Lise öğrencilerinin bilim insanı imajları ve bilimin doğası mitleri. Ahi Evran Üniversitesi Kırşehir Ĕ̆itim Fakültesi Dergisi, 18(2), 19-36. 
Gül, Ş. ve Erkol, M. (2016). An investigation of prospective science teachers' conceptions towards the nature of scientific knowledge. Journal of Theoretical Educational Science, 9(4), 642-661. https:/ / doi.org/10.5578/keg.10871

Hand, B., Prain, V., Lawrence, C., and Yore, L. D. (1999). A Writing in science framework designed to improve science literacy. International Journal of Science Education, 10, 1021-1036. https://doi.org/10.1080/095006999290165

Kardaş, S., ve Şahin, F. (2020). Bilimsel hikâyelerin 6. sınıf öğrencilerinin akademik başarılarına ve bilimin doğasını anlamalarına etkisinin incelenmesi. IBAD Sosyal Bilimler Dergisi, (7), 222-234. https:/ / doi.org/10.21733/ibad.686456

Kartal, E. E. ve Ada, E. (2018). Okul öncesi öğretmen adaylarının bilimin doğası hakkındaki görüşleri. Cumhuriyet Uluslararası Ĕ̆itim Dergisi, 7(1), 84-101.

Khishfe, R. (2013). Transfer of nature of science understandings into similar contexts: promises and possibilities of an explicit reflective approach. International Journal of Science Education, 35(17), 2928-2953. https://doi.org/10.1080/09500693.2012.672774

Koçyiğit, A. ve Pektaş, M. (2017). Ortaokul fen bilimleri ders kitaplarındaki okuma parçalarının bilim tarihi kullanımı açısından incelenmesi. Cumhuriyet International Journal of Education, 6(1), 185-199. https://doi.org/10.30703/cije.321452

Küçük, M. (2006). Bilimin doğasını ilköğretim 7. sınıföğrencilerine öğretmeye yönelik bir çalışma. (Yayımlanmamış doktora tezi). Karadeniz Teknik Üniversitesi, Trabzon.

Lederman, N. G. (1992). Students' and teachers' conceptions of the nature of science: A review of the research. Journal of Research in Science Teaching, 29(4), 331-359. https://doi.org/10.1002/tea.3660290404

Lederman, N. G. (2007). Nature of science: Past, present, and future. In Abell, S. K., and Lederman, N. G. (Eds.), Handbook of Research On Science Education, 831-879. London, Lawrence Erlbaum Associates.

Millî Eğitim Bakanlığı (2013). İlköğretim kurumları (ilkokullar ve ortaokullar) fen bilimleri dersi $(3,4$, 5, 6, 7 ve 8. sinıflar) öğretim programı. Ankara: Devlet Kitapları Basım Evi.

Milli Eğitim Bakanlığı [MEB]. (2018). Fen bilimleri dersi öğretim programı (ilkokul ve ortaokul 3, 4, 5, 6, 7 ve 8. sinıflar) öğretim programı. Ankara: Devlet Kitapları Basım Evi.

Moss, M. D. (2001). Examining Student Conceptions of the Nature of Science. International Journal of Science Education, 23(8), 771-790. https://doi.org/10.1080/09500690010016030

National Research Council (NRC) (1996). National science education standards. National Academic Press: Washington, DC.

Nacaroğlu, O., ve Arslan, M. (2020). Özel yetenekli öğrencilerin bilim insanı imajlarının ve bilim insanının özelliklerine yönelik görüşlerinin incelenmesi. Cumhuriyet Uluslararası Eğitim Dergisi, 9(2), 332-348.

Ozan, F. ve Uluçınar-Sağır (2020). FeTeMM etkinliklerinin ortaokul öğrencilerinin bilimin doğası hakkındaki görüşlerine etkisi. Journal of STEAM Education, 3(2), 32-43.

Özkal, K. (2007). Scientific epistemological beliefs, perceptions of constructivist learning environment and attitude towards science as determinants of students approaches to 
learning. (Unpublished Master Thesis). Middle East Technical University, Ankara.

Öztürk, M. ve Kaplan, N. (2014). Common fixed points of f-contraction mappings in complex valued metric spaces. Mathematical Sciences, 8(2), 129.

https:/ / doi.org/10.1007/s40096-014-0129-2

Rubba, P. A., and Andersen, H. O. (1978). Development of an instrument to assess secondary school students' understanding of the nature of scientific knowledge. Science Education, 62(4), 449-458. https:/ / doi.org/10.1002/sce.3730620404

Sağdıç, M. (2018). Rehberli sorgulama öğretim modeline göre fen eğitiminin ortaokul ögrrencileri üzerindeki etkisinin incelenmesi: Kuvvet ve enerji ünitesi örneği. (Yüksek lisans tezi). Van Yüzüncü Y1l Üniversitesi: https://doi.org/10.23891/efdyyu.2019.148

Takaoğlu, B. (2018). Lise öğrencilerinin bilim tarihi hakkındaki bilgi düzeyleri. Mavi Atlas, 6(1), 349-370. https://doi.org/10.18795/gumusmaviatlas.419094

Taşar, M. F. (2006). Probing pre-service teachers' understandings of scientific knowledge by using a vignette in conjunction with a paper and pencil test. Eurasia Journal of Mathematics, Science and Technology Education, 2(1), 53- 70. https://doi.org/10.12973/ ejmste/75438

Url-1, (2020). http:/ / turkyaybir.org.tr/milli-egitim-bakanligi-ders-kitaplari-veegitim-araclari-yonetmeligi/\#.X81Ge1UzaY1 03.12. 2020 tarihinde erişilmiştir.

Wood, L. C. (2012). Conceptual change and science achievement related to a lesson sequence on acids and bases among African American alternative high school students: A teacher's practical arguments and the voice of the other. (Thesis of Doctoral). Wayne State University.

Yenice, N. ve Ceren-Atmaca, A. (2017). Fen bilgisi öğretmen adaylarının bilimin ve bilimsel bilginin doğasına yönelik bilgi ve görüşlerinin belirlenmesi. Kuramsal Eğitimbilim Dergisi, 10(4), 366-393. https:/ / doi.org/10.5578/keg.27943

Yıldırım, İ. ve Bakırcı, H. (2020). Ortak bilgi yapılandırma modeline dayalı fen öğretiminin sekizinci sınıf öğrencilerinin sosyobilimsel konular hakkındaki görüşlerine yansımasının incelenmesi. İnönü Üniversitesi Eğitim Fakültesi Dergisi, 21(2), 1051-1070. https:/ / doi.org/10.17679/inuefd.735702

Yıldırım, A. ve Şimşek, H. (2013). Sosyal bilimlerde nitel araştırma yöntemleri. Ankara: Seçkin Yayınevi.

\section{Summary}

\section{Introduction}

The learning process carried out with CKCM may change the views on the nature of science. Socio-scientific issues of CKCM and the nature of science and entrepreneurship have an important role in the Science Course Curriculum (MoNE, 2018). Therefore, CKCM in science courses can contribute to the purpose of the program (Bakırc1 et al., 2017). In the second phase of CKCM, identifying students' scientific knowledge can not only be obtained by experimentation, observation, and proving, but can also be revealed through social dimensions such as interview, sharing, and negotiation. The use of such diverse methods can support the use of CKCM in teaching the nature of science (Biernacka, 2006; Ebenezer \& Connor, 1998). 
Also, scientific discourse is important for social construction under the guidance of teachers in CKCM (Duschl \& Osborne, 2002). This supports one of the contents of the nature of science. In general, the use of CKCM in the Science course will contribute to the literature. This research aims to seek an answer to the following question: Does science teaching based on the CKCM have an effect on eighth grade students' nature of scientific knowledge? The following research questions formed the basis of this research:

Is there a statistically significant difference between the experimental and the control group students' pre-test scores of the Nature of Scientific Knowledge Scale (NSKS)?

Is there a statistically significant difference between the NSKS pre-test and posttest scores of the experimental and control group students?

Is there a statistically significant difference between the NSKS post-test scores of the experimental and control group students?

\section{Method}

This research employs quasi-experimental method and it was conducted in a rural secondary school in the town of Tusba, Van during the 2017-2018 academic year, with 50 students. There were two groups of students: 25 of whom were in experimental group (10 girls, 15 boys) and 25 of them were in the control group ( 9 girls, 16 boys).

The research lasted 6 weeks ( 24 lesson hours). The Unit of Structure and Properties of Matter was used during the intervention. The intervention in the experimental and control groups was carried out on the basis of the Science Curriculum (2018). In the control group, the lessons were conducted with the 5E learning model based on inquiry-based learning approach. In the experimental group, lessons were taught according to CKCM.

In this study, the Nature of Scientific Knowledge Scale (NSKS) developed by Rubba and Anderson (1978) was used. The scale was adapted to Turkish by Taşar (2006). Independent $t$-test from parametric tests was used for comparison of experimental and control groups, while dependent t-test was preferred for comparisons of groups within themselves.

\section{Findings}

While the arithmetic mean of the moral dimension of NSKS posttest scores of the students in the experimental group was 33.28, the arithmetic mean of the control group students was 30.95. There is a significant difference according to the post-test scores of the experimental and control groups, and this difference is seen to be in favor of the experimental group $\left[\mathrm{t}_{(45)}=3.79, \mathrm{p}<.001\right]$. The arithmetic mean of the post-test scores of the creativity dimension of the NSKS of the experimental group students was determined as 32.20, and the arithmetic mean of the control group students as 31.50. No significant difference was found according to the post-test scores of the experimental and control groups $\left[\mathrm{t}_{(45)}=.919, \mathrm{p}>.05\right]$. When we look at the developmental dimension of the NSKS of the experimental group students, the arithmetic mean of the posttest scores was 33.48, and the arithmetic mean of the control group students was 30.86 . It was observed that there was a significant difference in the post-test scores of the experimental and control groups, and this difference was found to be in favor of the experimental group. $[\mathrm{t}(45)=5.24, \mathrm{p}<.001]$. It was observed that 
while the arithmetic mean of the parsimonious sub-scale post-test scores of the students in the experimental group was 30.96, the arithmetic mean of the students in the control group was 29.40. It is seen that there is a significant difference in the posttest scores of the experimental and control groups, and this difference is in favor of the experimental group $\left[\mathrm{t}_{(45)}=2.25, \mathrm{p}<.05\right]$. The arithmetic mean of the testable subscale of the posttest scores of the students in the experimental group was found to be 32.52, and the arithmetic mean of the students in the control group was 30.13. It is seen that there is a significant difference in the post-test scores of the experimental and control groups, and this difference is in favor of the experimental group. $\left[t_{(45)}=2.84, p<.05\right]$. The arithmetic mean of the unified subscale of posttest scores of the students in the experimental group for the merging dimension of the MSKS was 33.72, while the arithmetic mean of the control group students was 31.09. It is seen that there is a significant difference according to the posttest scores of the experimental and control groups, and this difference is in favor of the experimental group $\left[\mathrm{t}_{(45)}=4.02, \mathrm{p}<.001\right]$.

\section{Discussion, Results and Recommendations}

When the NSKS posttest scores of the experimental and control groups were examined, it was found that there was a significant statistical difference in favor of the experimental group. This means CKCM-based science teaching applied in the experimental group was more effective on students' understanding of the nature of scientific knowledge compared to the $5 \mathrm{E}$ learning model applied in the control group. It can be said that this significant difference stems from the fact that CKCM focuses on different learning areas such as the nature of science, sociocentric issues and conceptual change. Teaching the elements of the nature of science to students is among these learning areas (Ebenezer, Chacko, Kaya, Koya, \& Ebenezer, 2010). In the first stage of CKCM, activities aim to reveal the prior knowledge of students about the nature of science, and in the third stage of the model, discussions are carried out on these issues.

The fact that the nature of scientific knowledge of the students in the experimental group is at a good level compared to the control group students can be directly related to the efficiency of these activities (Bakırcı \& Çiçek, 2017). The research of Biernacka (2006) with fifth grade students concluded that the activities developed based on CKCM were effective on the experimental element of the students' nature of science. Bakırcı and Çiçek (2017) found that CKCM contributes to the understanding of the elements of the nature of science such as observation and inference, imagination, creativity in students. Understanding the elements of the nature of science by students contributes to their conceptualization of the nature of scientific knowledge (Caymaz \& Aydin, 2019).

In order to see the effect of science teaching based on CKCM and to understand the nature of scientific knowledge more clearly, it is recommended to use the model in different education levels. Since CKCM-based science teaching has an effect on students 'views on the nature of science, it is thought that using this model in the Science course will contribute to students' science literacy skills.

The use of CKCM in the Science course can contribute to students' learning of the nature of scientific knowledge. 


\section{Araştırmanın Etik Taahhüt Metni}

Yapılan bu çalışmada bilimsel, etik ve alıntı kurallarına uyulduğu; toplanan veriler üzerinde herhangi bir tahrifatın yapılmadığı, karşılaşılacak tüm etik ihlallerde "Cumhuriyet Uluslararası Eğitim Dergisi ve Editörünün" hiçbir sorumluluğunun olmadığ1, tüm sorumluluğun Sorumlu Yazara ait olduğu ve bu çalışmanın herhangi başka bir akademik yayın ortamına değerlendirme için gönderilmemiş olduğu sorumlu yazar tarafından taahhüt edilmiştir.

\section{Authors' Biodata/Yazar Bilgileri}

İlke YILDIRIM Milli Eğitim Bakanlığı'nda Fen Bilimleri öğretmeni olarak çalışmaktadır. Van Yüzüncü Yıl Üniversitesi Eğitim Bilimleri Enstitüsü’nde Yüksek Lisans tez çalışmasını tamamlamıştır.

Ilke Yildirim works as a science teacher at the Ministry of National Education. She completed her master's thesis at Van Yüzüncü Yll University, Institute of Educational Sciences.

Hasan BAKIRCI fen eğitimi alanında uzmandır. Lisansını Van Yüzüncü Yı1 Üniversitesi Eğitim Fakültesi'nde ve yüksek lisansını Van Yüzüncü Yıl Üniversitesi Fen Bilimleri Enstitüsü'nde tamamlamıştır. Ortak Bilgi Yapılandırma Modeli'nin fen öğretiminde kullanımı konusunda Karadeniz Teknik Üniversitesi Eğitim Bilimler Enstitüsü'nde doktorasını yapmıştır. Fen öğretiminde kullanılan öğretim yaklaşımları, modelleri ve yöntemleri üzerinde çalışmalar yapmaktadır. Ayrıca kavram öğretimi ve FeTeMM konuları üzerinde çalışmalarına devam etmektedir. Şu an Van Yüzüncü Yıl Üniversitesi'nde Eğitim Fakültesi'nde Doçent olarak çalışmaktadır.

Hasan Bakirci is an expert in science education. He completed his bachelor at Van Yüzüncü Yıl University Faculty of Education and his master's degree at Van Yüzüncü Y1l University, Institute of Science. He completed his doctorate at Karadeniz Technical University Institute of Educational Sciences on the use of Common Knowledge Construction Model in science teaching. He works on teaching approaches, models and methods used in science teaching. In addition, he continues to work on concept teaching and STEM. He is currently working as an Associate Professor in the Faculty of Education at Van Yüzüncü Yil University. 